Dhaka Univ. J. Biol. Sci. 26(1): 45-58, 2017 (January)

\title{
16S rRNA GENE SEQUENCE BASED IDENTIFICATION OF VIBRIO SPP. IN SHRIMP AND TILAPIA HATCHERIES OF BANGLADESH
}

\author{
Md Abdur Razzak Hasan, Mohammad Anwar Siddique ${ }^{1}$, Mahmud Hasan, \\ M AnWar Hossain ${ }^{1}$ and Mohammad SHAMsur RaHMaN* ${ }^{*}$ \\ Department of Fisheries, Faculty of Biological Sciences, \\ University of Dhaka, Dhaka-1000, Bangladesh
}

Key words: Vibrio spp., Shrimp hatchery, Tilapia hatchery, $16 \mathrm{~S}$ rRNA gene

\begin{abstract}
Presence of Vibrio spp., one of the deadliest fish and shrimp pathogens in aquaculture facilities worldwide for which hatchery owners often suffer hectic economic losses, were identified in shrimp and tilapia hatcheries of Cox's Bazar and Mymensingh, Bangladesh. Thirty seven Vibrio isolates, selected on the basis of their morphological dissimilarities in thiosulphate citrate bile salt sucrose agar (TCBS) plate, were subjected to amplified $16 \mathrm{~S}$ ribosomal DNA restriction analysis (ARDRA) by using $A l u \mathrm{I}$ restriction enzyme following their DNA extraction and amplification of 16S rRNA (1450 bp). From this analysis, representative isolates of 8 ARDRA groups, named as ARH 1 to ARH 8, of different band patterns were sequenced and identified as Vibrio alginolyticus, Aeromonas veronii, A. hydrophila, Vibrio vulnificus, V. cholerae, Edwardsiella hoshinae, Bacillus methylotrophicus and Aeromonas veronii, respectively. Vibrio species identified in this study are pathogenic for human and aquatic organisms, and were found only in shrimp hatchery with the dominance of $V$. alginolyticus. Findings of this study indicate the poor quality of water treatment and management of the hatchery. It was also observed that all the three Vibrio species were present in the Artemia rearing tank which indicates the possible source of pathogens.
\end{abstract}

\section{Introduction}

To date, 130 species of Vibrio have been described and 12 were classified as human pathogens implicated mostly in food- or water-borne diseases, including $V$. cholerae as the main cause of diarrhoea, $V$. parahaemolyticus as the cause of food-borne gastroenteritis and $V$. vulnificus which is known to cause $95 \%$ of all deaths associated with seafood consumption $^{(1)}$. Other pathogenic species include $V$. alginolyticus, $V$. damsela, $V$. fluvialis, $V$. furnissii, $V$. hollisae, $V$. metschnikovii and $V$. mimicus (2). Some vibrios may cause disease in both aquatic animals and humans. Austin (2010) categorizes $V$. cholerae, $V$. parahaemolyticus and V. vulnificus as high risk organisms for zoonoses, and Grimontia (=Vibrio) hollisae, Photobacterium (=Vibrio) damselae subsp. damselae, V. alginolyticus, $V$. harveyi, $V$. fluvialis, $V$. furnissii, $V$. metschnikovii and $V$. mimicus as low risk organisms ${ }^{(3)}$.

*Author for correspondence: <shamsur@du.ac.bd>. ${ }^{1}$ Department of Microbiology, Faculty of Biological Sciences, University of Dhaka, Dhaka-1000, Bangladesh. 
Vibrios occur in a wide range of aquatic environments, including estuaries, marine coastal waters, and aquaculture settings worldwide ${ }^{(4)}$. Several cultivation-dependent and independent studies have shown that Vibrios appear particularly in high densities in and/or on marine organisms, e.g., fish(5), shellfish $^{(6)}$, shrimps ${ }^{(7)}$. Vibriosis caused by Vibrio spp., is one of the most prevalent diseases in fishes and other aquaculture-reared organisms and is widely responsible for mortality in aquaculture systems worldwide( ${ }^{(8)}$. Due to intensification and feeding loads modern intensive shrimp systems provide almost ideal conditions for the propagation of diseases like vibriosis ${ }^{(9)}$. During outbreaks in larval and postlarval shrimp rearing, luminescent $V$. harveyi, $V$. campbellii, and probably $V$. splendidus have been isolated. Vibrios are considered opportunistic pathogens, but evidence suggests that some strains can be regarded as primary pathogens, especially in the case of V. penaeicida. Artemia spp. can also be susceptible to infection by Vibrios, as is the case of $V$. proteolyticus and strains of $V$. parahaemolyticus and V. campbellii(10).

Disease prevalence has increased with intensification of aquaculture and with increased fisheries production in Bangladesh. However, virulence of pathogens, especially bacterial diseases caused by Vibrio spp. has been found to be a crisis in the shrimp industry over the last few years ${ }^{(11)}$. Aquaculture industries of both saltwater and freshwater are becoming increasingly vulnerable to bacterial infection due to easy transmission of pathogens within farm area. Diseases caused by Vibrio spp. and Aeromonas spp. are commonly found to cause mortality ${ }^{(12)}$. These pathogens cause serious infections, decreased production both in the hatchery and grow-out ponds, reduced feed conversion and growth rates in surviving individuals, thus having a negative impact on the overall financial efficiency of the business. That is why efficient methods for detection, differentiation and characterization of Vibrio spp. are required to be included in screening programs in order to prevent infections and diseases associated with the pathogenic strains. However, little is known on the prevalence of Vibrio spp. in Bangladesh, except for $V$. cholerae ${ }^{(13)}$. Therefore, it is of utmost importance to detect the prevalence of vibrios in shrimp and fish hatcheries as a basis for preventive protection policy as well as public health concern.

Identification of the causative organisms up to the species level is very useful as it helps in determining the exact source of any outbreak and in devising strategies to reduce the severity of the disease. However, the conventional identification techniques involving a series of biochemical tests and agglutination with specific antisera are timeconsuming and ambiguous ${ }^{(14)}$. Therefore, there is a need to characterize the sample isolates by $16 \mathrm{~S}$ rRNA gene sequencing for species-specific identification of Vibrios. The objective of the study was to understand the prevalence of Vibrio community in the sampled shrimp and tilapia hatcheries of Bangladesh using culture and molecular techniques. 


\section{Materials and Methods}

Sample collection and preparation: A total of 30 samples, 16 from coastal shrimp hatchery of Cox's Bazar and the rest 14 from tilapia hatchery of Mymensingh, have been collected and examined. The sampling was done during June, 2015 to August, 2015. The samples include shrimp post larvae (PL), artemia (live feed) nauplii, fry of cultured tilapia and the cultured water. Collected samples were kept in icebox maintaining temperature at $-4^{\circ} \mathrm{C}$ and kept at $-20^{\circ} \mathrm{C}$ after transferring in the laboratory. All samples were collected following the method of American Public Health Association (15). Fry and PL samples were aseptically grinded in a mortar and blended with physiological saline $(0.85 \% \mathrm{NaCl})$. The water samples were kept just as it was. All blended samples were kept at a distance to reduce cross contamination.

Isolation of bacteria: Alkaline peptone water (APW) was used for the enrichment of the samples in order to provide a suitable environment for Vibrio spp. to grow and reach a detectable level for the presumptive identification. One $\mathrm{ml}$ blended solution from each sample was taken in $9 \mathrm{ml}$ alkaline peptone water in a test tube. These tubes were kept in the incubator at $37^{\circ} \mathrm{C}$ for 6 to $24 \mathrm{hrs}$. After the incubation period, $2 \beta$ loopful of culture were transferred to TCBS agar media aseptically and then streaked. The streaked TCBS plates were kept in the incubator at $37^{\circ} \mathrm{C}$ over a period of $24 \mathrm{hrs}$. After observing the morphology of bacterial colonies which grew in the TCBS, only single colonies with dissimilar traits were picked and then subcultured in new TCBS plates. The subcultured single colonies were further screened on their morphological appearance and only variant isolates were stored in Luria-Bertani (LB) broth supplemented with $30 \%$ glycerol at $-80^{\circ} \mathrm{C}$ for future use.

Molecular analysis of the isolates for identification: Chromosomal DNA of the selected 37 isolates was extracted followed by amplification of the 16S rRNA gene of the isolates by polymerase chain reaction (PCR) and amplified ribosomal DNA restriction analysis (ARDRA) to group the isolates into different genotypes. 16S rRNA gene amplicons of selected representative isolates of each genotype were sequenced followed by phylogenetic analysis to unveil the phylogenetic relatedness.

The conserved region of $16 \mathrm{~S}$ rRNA of the isolates was amplified by PCR for further analysis. The sequences of oligonucleotide primers used for amplification of the ribosomal subunit $16 \mathrm{~S}$ rRNA were as follows: 27F 5' - AGA GTT TGA TCM TGG CTC AG $-3^{\prime \prime(16)}$ and 1492R 5'- CGG TTA CCT TGT TAC GAC TT-3'(17), with an approximate length of $1500 \mathrm{bp}$. Reactions of the amplification were conducted in a reaction volume of $15 \mu \mathrm{l}$ containing $7.5 \mu \mathrm{l}$ of GoTaq ${ }^{\circledR}(2 X)$ Master Mix, $1.5 \mu$ of DNA template, $4.5 \mu l$ of nucleasefree water, $0.75 \mu \mathrm{l}$ of each forward and reverse primer. PCR amplification was done in a thermal cycler (Veriti 96-Well Thermal Cycler, Applied Biosciences, USA). The program initially consisted of the following steps: $94^{\circ} \mathrm{C}$ for $5 \mathrm{~min}$ for denaturation, then 40 cycles at $94^{\circ} \mathrm{C}$ for $1 \mathrm{~min}, 57^{\circ} \mathrm{C}$ for $1 \mathrm{~min}$ and $72^{\circ} \mathrm{C}$ for $1 \mathrm{~min} 30 \mathrm{~s}$, followed by an extension step 
at $72^{\circ} \mathrm{C}$ for $7 \mathrm{~min}$. Successful amplification of the desired genes was visualized by resolving the PCR products in 1\% agarose gel $(\mathrm{w} / \mathrm{N})$. One $\mathrm{kb}$ DNA ladder (Promega, USA) was also electrophoresed along the side of the amplified sample DNA, which served as a reference for the determination of the molecular weights of the fragments obtained in the PCRs. The gel was viewed using Alpha Imager HP Gel-documentation system (Cell Bioscience, USA).

Table 1. List of samples collected from Cox's Bazar (shrimp hatchery) and Mymensingh (tilapia hatchery).

\begin{tabular}{|c|c|c|c|}
\hline \multicolumn{2}{|c|}{ Shrimp hatchery of Cox's Bazar } & \multicolumn{2}{|c|}{ Tilapia hatchery of Mymensingh } \\
\hline $\begin{array}{l}\text { Sample } \\
\text { ID }\end{array}$ & Sample & $\begin{array}{l}\text { Sample } \\
\text { ID }\end{array}$ & Sample \\
\hline $\mathrm{C} 1$ & Artemia nauplii from Tank 1 & M1 & Tilapia fry, 40 days \\
\hline $\mathrm{C} 2$ & Artemia nauplii from Tank 2 & M2 & $"$ \\
\hline C3 & Shrimp PL of 10 days, Tank 1 & M3 & $"$ \\
\hline $\mathrm{C} 4$ & Water from PL (10) Tank 1 & M4 & Tilapia fry, 25 days \\
\hline C5 & Shrimp PL of 10 days, Tank 2 & M5 & $"$ \\
\hline C6 & Water from PL (10) Tank 2 & M6 & " \\
\hline C7 & Shrimp PL of 12 days & M7 & Tilapia fry, 28 days \\
\hline $\mathrm{C} 8$ & Water from PL (12) Tank & M8 & $"$ \\
\hline C9 & Artemia nauplii from Tank 1 & M9 & " \\
\hline $\mathrm{C} 10$ & Artemia nauplii from Tank 2 & M10 & Tilapia fry, 33 days \\
\hline C11 & Shrimp PL of 8 days & M11 & " \\
\hline C12 & Water from PL (8) Tank & M12 & $"$ \\
\hline C13 & Shrimp PL of 12 days & M13 & Water from hapa- Tilapia of 25 days \\
\hline C14 & Water from PL (12) Tank & M14 & $"$ \\
\hline C15 & Shrimp PL of 10 days & & \\
\hline $\mathrm{C} 16$ & Water from PL(10) Tank & & \\
\hline
\end{tabular}

Amplified ribosomal DNA restriction analysis (ARDRA): Enzymatic digestion of $16 \mathrm{~S}$ rRNA gene amplicons of the 37 presumptive Vibrio isolates was performed using the AluI (Promega, USA) restriction enzyme. The restriction digestion (20 $\mu$ l of final volume) was carried out for $4 \mathrm{hrs}$ at $37^{\circ} \mathrm{C}$. The preparation for the reaction was done in a reaction volume of $20 \mu \mathrm{l}$ containing $0.5 \mu \mathrm{l}$ of $A l u \mathrm{I}$ restriction enzyme, $2 \mu \mathrm{l}$ of reaction buffer, $3 \mu \mathrm{l}$ of template and $14.5 \mu \mathrm{l}$ of nuclease free water. The resulting digestion products were resolved by agarose gel electrophoresis using $2 \%$ agarose $(\mathrm{w} / \mathrm{N})$.

$16 S$ rRNA gene sequencing and phylogenetic analyses: The PCR products of specific genes were purified with the Wizard PCR SV Gel and PCR CleanUp System kit (Promega, USA) according to the manufacturer's instruction prior to sequencing. The PCR products were sent to First BASE Laboratories Sdn Bhd (Malaysia) where the cycle 
sequencing was performed using BigDye ${ }^{\circledR}$ Terminator v3.1 Cycle Sequencing kit (Applied Biosystems ${ }^{\circledR}$, USA) according to manufacturer's instruction and extension product was purified followed by capillary electrophoresis using ABI genetic analyzer (Applied Biosystems ${ }^{\circledR}$, USA). Bidirectional ( $5^{\prime}$ to $3^{\prime}$ and $3^{\prime}$ to $5^{\prime}$ ) sequences were done for all 8 representative isolates.

Geospiza's Finch TV version 1.4 was used to view DNA sequences. Homology searching using BLAST (Basic Local Alignment Search Tool) (http:/历last.ncbi.nlm.nih. gov) was executed for comparing primary sequence identity. MEGA v 6.0(18) was used for the comparative analysis of molecular sequence data for reconstructing the phylogeny. Distance matrices were calculated using Kimura's 2-parameter distances. Robustness of topologies were assessed by the bootstrap method with 1,000 replicates.

Nucleotide sequence accession numbers: The reported sequences in this study have been submitted to NCBI GenBank database under accession numbers KY084544-KY084551.

\section{Results and Discussion}

Isolation of presumptive Vibrio spp.: Green, yellow and other colored colonies were selected from TCBS cultures and were then streaked on Luria Bertani Agar (LBA; with $3 \% \mathrm{NaCl}$ supplementation). On TCBS, yellow colonies were presumptively identified as $V$. alginolyticus, $V$. cholerae, $V$. fluvialis, $V$. metschnikovii and $V$. furnissii. Green or blue-green colonies were assumed to be $V$. parahaemolyticus, $V$. vulnificus and $V$. mimicus. A total of 37 pure colonies were selected by TCBS, from the 30 samples collected from Cox's Bazar and Mymensingh. Presumptive Vibrio colonies were screened from the TCBS media based on their morphological dissimilarities (Table 2) so that as many variations as possible could be taken for further confirmation through molecular approaches.

\section{Identification of the presumptive Vibrio isolates}

Amplified Ribosomal DNA Restriction Analysis (ARDRA): The genomic DNAs purified from the 37 suspected Vibrio colonies were subjected to a polymerase chain reaction in order to amplify their respective $16 \mathrm{~S}$ rDNA. Four isolates $(5,6,14$ and 21$)$ did not amplify with the primers. These produced amplicons of about $1450 \mathrm{bp}$, which were used as substrate for cleavage by a restriction enzyme, AluI to address their ARDRA pattern. The pattern produced eight different groups for all of the 37 isolates (Fig. 1). The corresponding bacterial isolates respective to each ARDRA group and the best representative colony from each group is summarized in Table 3. The ARDRA approach was practiced in this study for the purpose of accurate grouping among the morphologically dissimilar isolates. Grouping of isolates reduces the time and cost of molecular identification ${ }^{(19)}$. AluI, the restriction enzyme used in ARDRA, was best recommended by Szczerba et al. 2009(20). 
Table 2. Thirty seven presumptive Vibrio isolates and their colony morphology in TCBS plate that were selected for molecular analysis.

\begin{tabular}{|c|c|c|c|c|c|c|}
\hline Colony ID & Sample ID & Color & Size & Shape & Elevation & Surface \\
\hline 1 & $\mathrm{C} 1$ & Yellow & Medium & Round & Convex & Smooth \\
\hline 2 & C3 & Blue & Medium & Round & Flat & Smooth \\
\hline 3 & C6 & Yellow & Small & Round & Convex & Smooth \\
\hline 4 & $\mathrm{C} 7$ & Yellow & Medium & Round & Convex & Smooth \\
\hline 5 & C9 & Greyish-green & Small & Irregular & Raised & Smooth \\
\hline 6 & $\mathrm{C} 10$ & Green & Small & Round & Flat & Smooth \\
\hline 7 & $\mathrm{C} 11$ & Yellow & Large & Round & Convex & Smooth \\
\hline 8 & $\mathrm{C} 12$ & Yellow & Medium & Round & Convex & Smooth \\
\hline 9 & $\mathrm{C} 13$ & Greenish black & Large & Round & Convex & Smooth \\
\hline 10 & C14 & Yellow & Large & Round & Convex & Smooth \\
\hline 11 & $\mathrm{C} 15$ & Yellow & Small & Round & Convex & Smooth \\
\hline 12 & $\mathrm{C} 16$ & Yellow & Small & Round & Convex & Smooth \\
\hline 13 & $\mathrm{C} 7$ & Yellow & Small & Round & Raised & Smooth \\
\hline 14 & C9 & Dark green & Small & Round & Convex & Smooth \\
\hline 15 & $\mathrm{C} 10$ & Green & Medium & Round & Convex & Smooth \\
\hline 16 & $\mathrm{C} 2$ & Yellow & Large & Round & Raised & Smooth \\
\hline 17 & C3 & Blue & Small & Round & Convex & Smooth \\
\hline 18 & C5 & Blue & Medium & Round & Convex & Smooth \\
\hline 19 & M1 & Dark green & Medium & Round & Convex & Smooth \\
\hline 20 & M3 & Blue green & Medium & Round & Convex & Smooth \\
\hline 21 & M4 & Greenish & Small & Irregular & Convex & Smooth \\
\hline 22 & M5 & Blue green & Medium & Round & Convex & Smooth \\
\hline 23 & M7 & Blue green & Small & Round & Convex & Smooth \\
\hline 24 & M7 & Greenish & Small & Round & Convex & Smooth \\
\hline 25 & M9 & Blue green & Medium & Round & Convex & Smooth \\
\hline 26 & M12 & Blue green & Medium & Round & Flat & Smooth \\
\hline 27 & M14 & Blue green & Small & Round & Convex & Smooth \\
\hline 28 & M1 & Blue & Medium & Round & Convex & Smooth \\
\hline 29 & M3 & Blue green & Small & Round & Convex & Smooth \\
\hline 30 & M5 & Blue green & Large & Irregular & Flat & Smooth \\
\hline 31 & M5 & Blue & Small & Round & Convex & Smooth \\
\hline 32 & M8 & Green & Small & Round & Convex & Smooth \\
\hline 33 & M8 & Blue green & Medium & Round & Convex & Smooth \\
\hline 34 & M11 & Blue green & Medium & Round & Convex & Smooth \\
\hline 35 & M12 & Dark green & Small & Round & Convex & Smooth \\
\hline 36 & M13 & Blue green & Medium & Round & Convex & Smooth \\
\hline 37 & M13 & Blue green & Medium & Round & Convex & Smooth \\
\hline
\end{tabular}



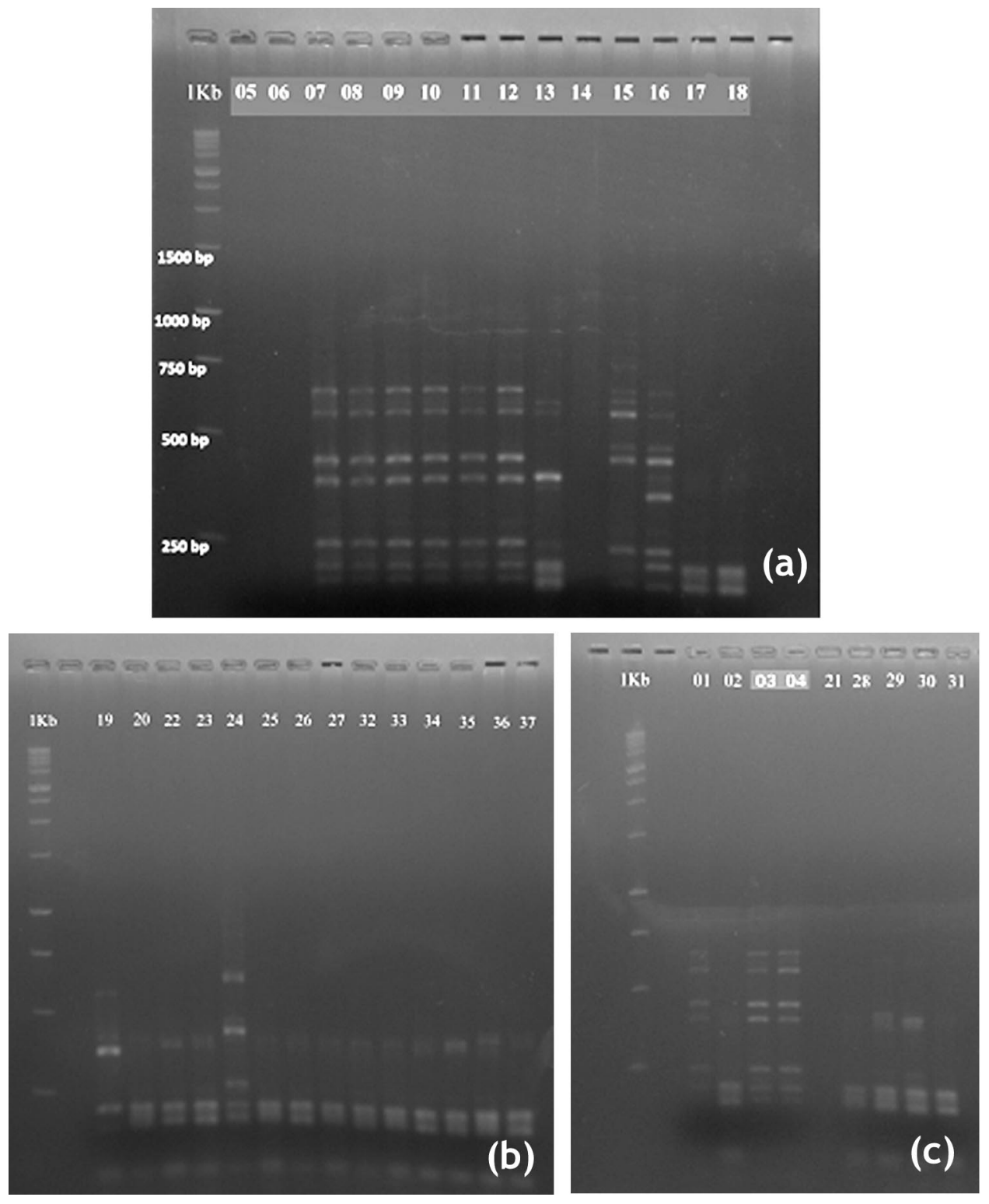

Fig. 1a-c: Denotes ARDRA pattern analysis of 37 isolates (four isolates did not amplify with $16 \mathrm{~S}$ rDNA primers). Restriction digestion of bacterial isolates using $A l u \mathrm{I}$ enzyme, the left most lane in all 3 figures indicates $1 \mathrm{~kb}$ DNA marker. The number above each lane represents the respective bacterial isolate.

$16 S$ rRNA sequence based identification: The identification of the $16 \mathrm{~S}$ rDNA gene sequences of eight representative isolates of the eight ARDRA groups (ARH 1, ARH 2, ARH 3, ARH 4, ARH 5, ARH 6, ARH 7 and ARH 8) through nucleotide BLAST of NCBI is summarised in Table 4. 
Table 3. The ARDRA group of 33 isolates of bacteria from shrimp and tilapia hatchery samples.

\begin{tabular}{lll}
\hline $\begin{array}{l}\text { ARDRA } \\
\text { group }\end{array}$ & $\begin{array}{l}\text { Representative } \\
\text { colony ID }\end{array}$ & $\begin{array}{l}\text { Colony } \\
\text { ID }\end{array}$ \\
\hline ARH 1 & 7 & $1,3,4,7,8,9,10,11,12$ \\
ARH 2 & 18 & $2,17,18,28,31$ \\
ARH 3 & 13 & 13 \\
ARH 4 & 15 & 15 \\
ARH 5 & 16 & 16 \\
ARH 6 & 19 & 19 \\
ARH 7 & 24 & 24 \\
ARH 8 & 26 & $20,22,23,26,25,27,29,30,32,33,34,35,36,37$ \\
\hline
\end{tabular}

Table 4. 16S rRNA sequence $(1320 \mathrm{bp})$ based identification of representative eight isolates from hatchery environment.

\begin{tabular}{|c|c|c|c|c|}
\hline Group & $\begin{array}{l}\text { Closest relative (obtained } \\
\text { from BLAST search) }\end{array}$ & $\begin{array}{l}\% \text { homology } \\
\text { with the } \\
\text { GenBank } \\
\text { sequence }\end{array}$ & $\begin{array}{l}\text { GenBank accession } \\
\text { number of } \\
\text { corresponding } \\
\text { sequence }\end{array}$ & $\begin{array}{l}\text { GenBank } \\
\text { accession number } \\
\text { of isolates under } \\
\text { present study }\end{array}$ \\
\hline ARH 1 & $\begin{array}{l}\text { Vibrio alginolyticus strain } \\
\text { PE2 16S rRNA }\end{array}$ & $100 \%$ & KT036618.1 & KY084544 \\
\hline ARH 2 & $\begin{array}{l}\text { Aeromonas veronii strain } \\
\text { WX153415 16S rRNA }\end{array}$ & $100 \%$ & КT964297.1 & KY084545 \\
\hline ARH 3 & $\begin{array}{l}\text { Aeromonas hydrophila } \\
\text { strain A-X4 16S rRNA }\end{array}$ & $99 \%$ & KJ806490.1 & KY084546 \\
\hline ARH 4 & $\begin{array}{l}\text { Vibrio vulnificus strain } \\
\text { FORC_009 chromosome } 2\end{array}$ & $99 \%$ & СР009985.1 & KY084547 \\
\hline ARH 5 & Vibrio cholerae strain BB31 & $100 \%$ & KF446244.1 & KY084548 \\
\hline ARH 6 & $\begin{array}{l}\text { Edwardsiella hoshinae } \\
\text { strain ATCC } 35051 \text { 16S } \\
\text { rRNA }\end{array}$ & $99 \%$ & KM676416.1 & KY084549 \\
\hline ARH 7 & $\begin{array}{l}\text { Bacillus methylotrophicus } \\
\text { strain LD34 16S rRNA }\end{array}$ & $100 \%$ & KR855694.1 & KY084550 \\
\hline ARH 8 & $\begin{array}{l}\text { Aeromonas veronii strain } \\
\text { K11 16S rRNA }\end{array}$ & $100 \%$ & KU041801.1 & KY084551 \\
\hline
\end{tabular}

As group ARH 1 is identified as Vibrio alginolyticus, all the isolates of this group can also be identified as Vibrio alginolyticus. Similar conclusions can also be drawn with the other groups about their corresponding isolates. In Table 5, a total summary of identification of all the isolates is shown with their corresponding sample name that were 
Table 5. Summary of molecular identification of the bacteria ( 33 isolates) isolated from shrimp and tilapia hatchery environments of Bangladesh.

\begin{tabular}{|c|c|c|c|c|}
\hline Group & Identified species & $\begin{array}{l}\text { Colony } \\
\text { ID }\end{array}$ & Sample ID & Sample \\
\hline \multirow[t]{9}{*}{ ARH 1} & \multirow{9}{*}{ Vibrio alginolyticus } & 1 & $\mathrm{C} 1$ & Artemia from Tank 1 \\
\hline & & 3 & C6 & Water from PL(10) tank \\
\hline & & 4 & C7 & Shrimp PL of 12 days \\
\hline & & 7 & C11 & Shrimp PL of 8 days \\
\hline & & 8 & $\mathrm{C} 12$ & Water from PL(8) tank \\
\hline & & 9 & C13 & Shrimp PL of 12 days \\
\hline & & 10 & C14 & Water from PL(12) tank \\
\hline & & 11 & C15 & Shrimp PL of 10 days \\
\hline & & 12 & C16 & Water from PL(10) Tank \\
\hline \multirow[t]{5}{*}{ ARH 2} & \multirow{5}{*}{ Aeromonas veronii } & 2 & $\mathrm{C} 3$ & Shrimp PL of 10 days \\
\hline & & 17 & C11 & Shrimp PL of 8 days \\
\hline & & 18 & $\mathrm{C} 5$ & Shrimp PL of 10 days \\
\hline & & 28 & M1 & Tilapia fry, 40 days \\
\hline & & 31 & M5 & Tilapia fry, 25 days \\
\hline ARH 3 & Aeromonas hydrophila & 13 & C7 & Shrimp PL of 12 days \\
\hline ARH 4 & Vibrio vulnificus & 15 & C10 & Artemia from Tank 2 \\
\hline ARH 5 & Vibrio cholerae & 16 & $\mathrm{C} 2$ & Artemia from Tank 1 \\
\hline ARH 6 & Edwardsiella hoshinae & 19 & M1 & Tilapia fry, 40 days \\
\hline ARH 7 & Bacillus methylotrophicus & 24 & M7 & Tilapia fry, 28 days \\
\hline \multirow[t]{14}{*}{ ARH 8} & \multirow{14}{*}{ Aeromonas veronii } & 20 & M3 & Tilapia fry, 40 days \\
\hline & & 22 & M5 & Tilapia fry, 25 days \\
\hline & & 23 & M7 & Tilapia fry, 28 days \\
\hline & & 25 & M9 & Tilapia fry, 28 days \\
\hline & & 26 & M12 & Tilapia fry, 33 days \\
\hline & & 27 & M14 & Water of 25 day old tilapia fry pond \\
\hline & & 29 & M3 & Tilapia fry, 40 days \\
\hline & & 30 & M5 & Tilapia fry, 25 days \\
\hline & & 32 & M8 & Tilapia fry, 28 days \\
\hline & & 33 & M8 & Tilapia fry, 28 days \\
\hline & & 34 & M11 & Tilapia fry, 33 days \\
\hline & & 35 & M12 & Tilapia fry, 33 days \\
\hline & & 36 & M13 & Water of 25 day old tilapia fry pond \\
\hline & & 37 & M13 & Water of 25 day old tilapia fry pond \\
\hline
\end{tabular}


collected from hatchery environments of Bangladesh. Three of eight representative isolates ARH 1, ARH 4 and ARH 5 were identified as Vibrio alginolyticus, Vibrio vulnificus and Vibrio cholerae, respectively. The table shows that the samples in which these Vibrio species were found were exclusively collected from the coastal environment of Cox's Bazar. Among these three groups, ARH 1, which was identified as Vibrio alginolyticus, represents the highest number of isolates including samples. Of the eight representative groups, three were identified as genus Vibrio (V. alginolyticus, $V$. vulnificus and $V$. cholerae), three Aeromonas (two A. veronii and one A. hydrophila), one Edwardsiella hoshinae and one Bacillus methylotrophicus. The dominance of Vibrio species in hatchery environments is well established(21,22). Interestingly, good number of isolates showed similarity with Aeromonas species even though TCBS (selective for Vibrio spp.) media was used for isolation. This might be due to the fact that Aeromonas spp. has partial inhibitory growth in TCBS agar media(23).

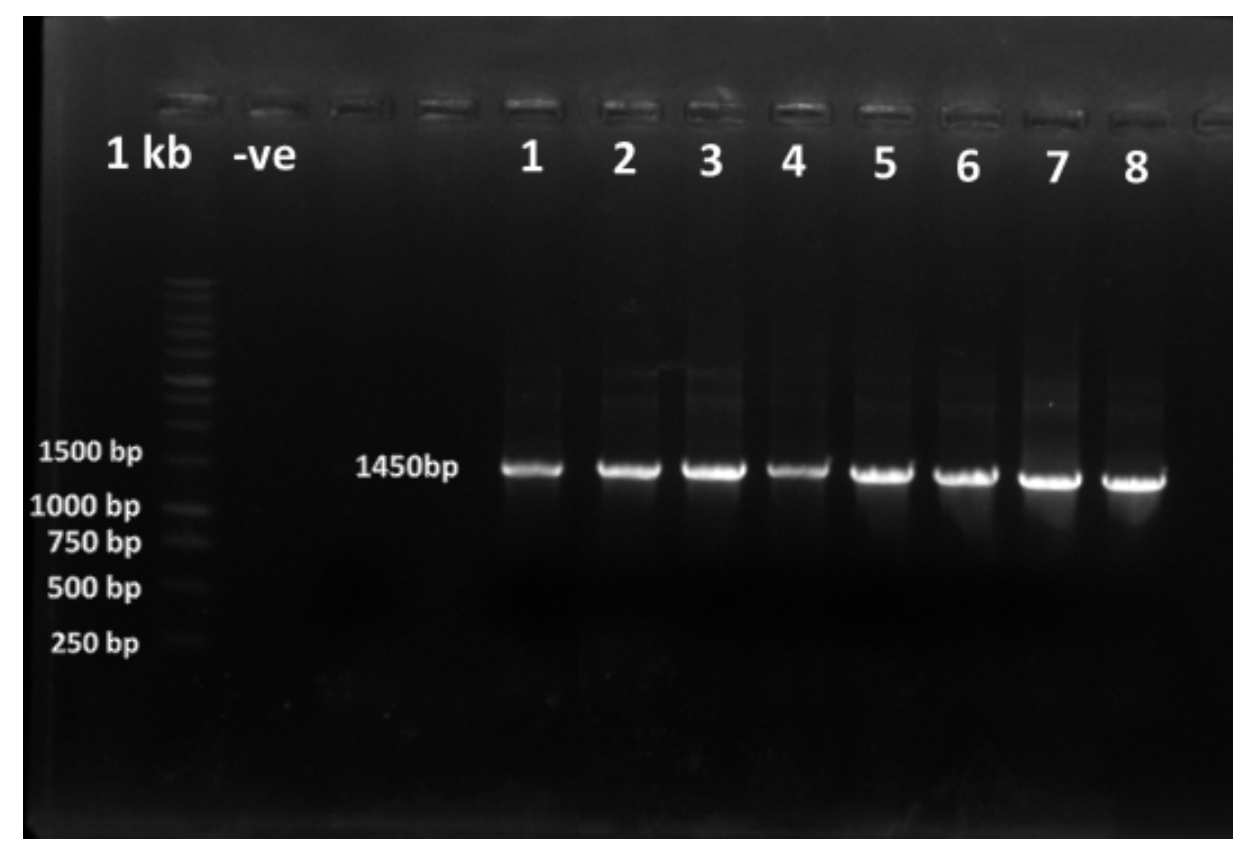

Fig. 2. Agarose gel (1\%) electrophoresis of $16 \mathrm{~S}$ rDNA gene of representative strains of eight ARDRA groups. The far left lane is $1 \mathrm{~kb}$ DNA ladder, while the next lane is used as negative control.

Phylogenetic analysis: The constructed phylogenetic tree involved a total of 18 (seven of our isolates and eleven downloaded from NCBI GenBank) nucleotide sequences to robust the positioning of isolates and to ascertain about their taxonomic position. The optimal tree with the sum of branch length $=0.24803246$ is shown. The percentage of 
replicate trees in which the associated taxa clustered together in the bootstrap test (1000 replicates) is shown next to the branches. There are a total of 1320 positions in the final dataset, which is in compliance with the recommended ideal guidelines (for less than $1 \%$ ambiguities) for use of $16 \mathrm{~S}$ rRNA gene sequencing for microbial identification.

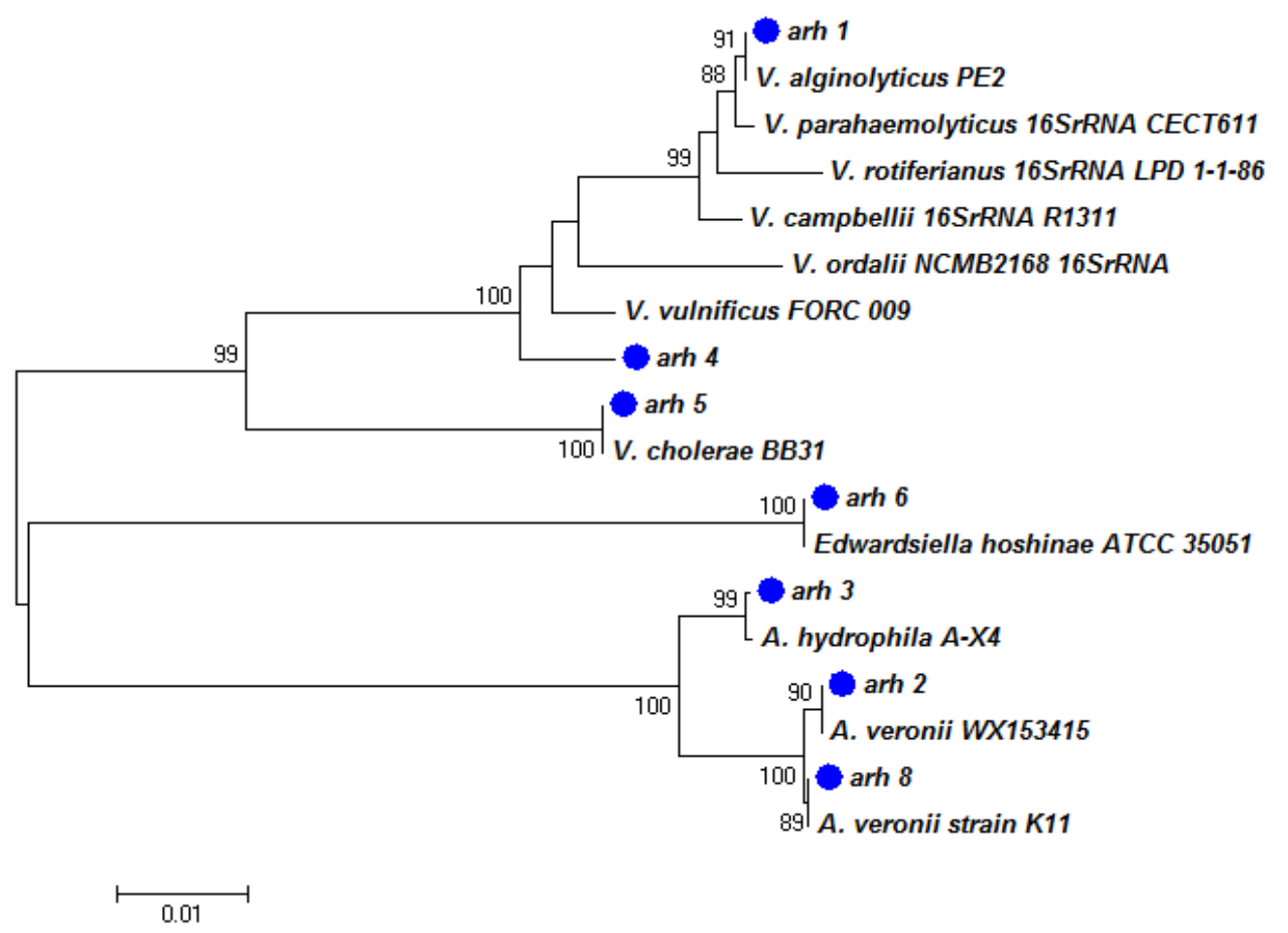

Fig. 3. The neighbour-joining (NJ) phylogenetic tree based on partial 16S rRNA gene sequences. The evolutionary distances were computed using the Maximum Composite Likelihood method. Numbers in tree are bootstrap values. Blue circle indicates position of the representative strains of seven ARDRA groups.

Phylogenetic analysis (Fig. 3) of the representative eight isolates confirmed the taxonomic position of the isolate ARH 1, ARH 4 and ARH 5 of the genus Vibrio, and allocated ARH 1 to the strain Vibrio alginolyticus PE2, ARH 4 to the strain Vibrio vulnificus FORC_009 and ARH 5 to the strain Vibrio cholerae BB31. From the tree it is also clear that ARH 1 is closely related to the strain of Vibrio parahaemolyticus CECT 611, V. rotiferianus LPD 1-1-86, V. campbellii R 1311, V. ordalii NCMB 2168 and V. vulnificus FORC 009. The phylogenetic tree confirms the taxonomic position of ARH 3, ARH 2 and ARH 8 in the genus Aeromonas supporting their similarity with the strain A. hydrophilla A-X4, A. veronii WX153415 and A. veronii K11, respectively. The taxonomic relation of ARH 6, which is allocated to Edwardsiella hoshinae ATCC 35051, is closer with the genus Aeromonas than with Vibrio spp. 
In the sequenced 8 representative isolates, 3 Vibrio species have been found among which the maximum number of isolates has been identified as Vibrio alginolyticus (ARH 1). The samples, in which these 3 Vibrio species are found, were exclusively collected from coastal environment. This finding is in agreement with the observation that occurrence of Vibrios is plentiful in marine and coastal environment than in freshwater ${ }^{10}$. However, in support of the current study, it might be stated that the dominance of $V$. alginolyticus in the shrimp hatchery samples was also found by another study(24). Felix (2000) also described V. alginolyticus as the most common Vibrio species in the shrimp hatchery environments(25). This species has been implicated as the causal agent of vibriosis or gas gut disease of many marine aquaria fishes ${ }^{(26)}$. V. alginolyticus is also described as a pathogen for shrimp farming(27). The presence of this bacterium also indicates its resistance against the treatments applied on the hatchery water.

The representative strain ARH 4 is identified as Vibrio vulnificus which is an established human pathogen ${ }^{(10)}$ and responsible for many food borne diseases ${ }^{(28)}$. Similar to the findings of this observation Rao et al. detected the bacteria only in shrimp hatchery samples ${ }^{(24)}$. The source of this strain was the water of artemia tank that was also accused as a source of $V$. harveyi in the works of Vaseeharan and Ramasamy ${ }^{(29)}$. Vibrio cholerae was found as the isolate ARH 5 which was also from the same source as V. vulnificus. The presence of this bacterium denotes fecal contamination in the water that might have happened due to poor sanitation or uncleanliness of the hatchery laborer or operators. This bacterium is a well-recognized human pathogen associated with cholera disease ${ }^{(10)}$.

\section{Conclusion}

This study describes the presence of Vibrio species in the sampled hatcheries and helps to comment on the quality of the hatchery environment. The presence of pathogenic $V$. alginolyticus, $V$. vulnificus and $V$. cholerae in the shrimp hatchery indicates a possibility of future outbreak of vibriosis and other diseases. The findings of this study also questions about the way of using live food (artemia) in the respective shrimp hatchery as all of the 3 pathogenic Vibrio species were found in the samples collected from the artemia tank. However, the absence of Vibrio species in the freshwater fish hatchery is not unquestionable and demands further research on this aspect.

\section{References}

1. Thompson FL, B Austin and J Swings 2006. The Biology of Vibrios, $1^{\text {st }}$ edn. ASM Press, Washington DC. pp. 423.

2. Pruzzo C, A Huq, RR Colwell and G Donelli 2005. Pathogenic Vibrio species in the marine and estuarine environment. In: Oceans and Health: Pathogens in the Marine Environment (Belkin S and RR Colwell Eds), $1^{\text {st }}$ edn. pp. 217-252. Springer, New York.

3. Austin B 2010. Vibrios as causal agents of zoonoses. Vet. Microbiol. 140(3-4): 310-317. 
4. Vandenberghe J, FL Thompson, B Gomez-Gil and J Swings 2003. Phenotypic diversity amongst Vibrio isolates from marine aquaculture systems. Aquaculture 219(1-4): 9-20.

5. Huys L, P Dhert, R Robles, F Ollevier, P Sorgeloos and J Swings 2001. Search for beneficial strains for turbot (Scophthalmus maximus L.) larviculture. Aquaculture 193 (1-2): 25-37.

6. Sawabe T, N Setogushi, S Inoue, R Tanaka, M Ootsubo, M Yoshimizu and Y Ezura 2003. Acetic acid production of Vibrio halioticoli from alginate: A possible role for establishment of abalone- $V$. halioticoli association. Aquaculture 219(1-4): 617-679.

7. Gomez-Gil B, L Tron-Mayen, A Roque, JF Turnbull, V Inglis and AL Guerra-Flores 1998. Species of Vibrio isolated from hepatopancreas, haemolymph and digestive tract of a population of healthy juvenile Penaeus vannamei. Aquaculture 163(1-2): 1-9.

8. Lavilla-Pitogo CR, EM Leano and MG Paner 1998. Mortalities of pond-cultured juvenile shrimp Penaeus monodon associated with dominance of luminescent vibrios in the rearing environment. Aquaculture 164(1-4): 337-349.

9. Zhang XJ, BL Yan, XS Bai, KR Bi, H Gao and GM Qin 2014. Isolation and characterization of Vibrio parahaemolyticus and Vibrio rotiferianus associated with mass mortality of chinese shrimp (Fenneropenaeus chinensis). J. Shellfish Res. 33(1): 61-68.

10. Gomez-Gil B, CC Thompson, Y Matsumura, T Sawabe, T Iida, T Christen, F Thompson and T Sawabe 2014. The Family Vibrionaceae. In: The Prokaryotes-Gammaproteobacteria (Rosenberg E, EF DeLong, S Lory, E Stackebrandt and F Thompson Eds.), 1 ${ }^{\text {st }}$ edn, Springer-Verlag Berlin Heidelberg. pp. 659-747.

11. Rahman S, SN Khan, MN Naser and M Karim 2010. Isolation of Vibrio spp. from penaeid shrimp hatcheries and coastal waters of Cox's Bazar, Bangladesh. Asian J. Exp. Biol. Sci. 1(2): 288-293.

12. Kesarcodi-Watson A, H Kaspar, MJ Lategan and L Gibson 2008. Probiotics in aquaculture: The need, principles and mechanisms of action and screening process. Aquaculture 274(1): $1-14$.

13. Rahman MS, Hasan M, Mahmud ZH and Islam MS 2009. Incidence of Vibrio cholerae in twelve freshwater fishes in fish markets of Dhaka metropolitan city, Bangladesh. Bangladesh J. Zool. 37(1): 113-121.

14. Sakazaki R 1992. Bacteriology of Vibrio and related organisms. In: Cholera (Barua D \& Greenough WB eds), $3^{\text {rd }}$ edn, pp 37-55. Plenum Medical Book Company, New York.

15. APHA 1998. Standard Methods for the Examination of Water and Wastewater. 20th edn. American Public Health Association, Washington DC. pp. 1325.

16. Lane DJ 1991. 16S/23S rRNA sequencing. In: Nucleic acid techniques in bacterial systematics (Stackebrandt E \& M Goodfellow Eds.), 1st edn, pp 115-163. John Wiley \& Sons, Chichester, England.

17. Frank JA, CI Reich, S Sharma, JS Weisbaum, BA Wilson and GJ Olsen 2008. Critical evaluation of two primers commonly used for amplification of bacterial $16 \mathrm{~S}$ rRNA genes. Appl. Environ. Microbiol. 74(8): 2461-2470.

18. Tamura K, G Stecher, D Peterson, A Filipski and S Kumar 2013. MEGA6: Molecular evolutionary genetics analysis version 6.0. Mol. Biol. Evol. 30(12): 2725-2729. 
19. De Baere T, R De Mendonça, G Claeys, G Verschraegen, W Mijs, R Verhelst and M Vaneechoutte 2002. Evaluation of amplified rDNA restriction analysis (ARDRA) for the identification of cultured mycobacteria in a diagnostic laboratory. BMC Microbiol. 2: 4.

20. Szczerba J, I Bednarek and Z Dzierżewicz 2009. ARDRA studies of the ribosomal RNA operon within the Desulfovibrio desulfuricans strains. Ann. Acad. Med. Siles. 63(1): 7-13.

21. Groumellec ML, P Haffner, B Martin and C Martin 1995. Comparative study of bacterial infections responsible for mass mortality in penaeid shrimp hatcheries of the pacific zone. In: Diseases in Asian Aquaculture II. (Shariff M, JR Arthur and RP Subasinghe Eds.). pp. 163-173. Fish Health Section, Asian Fisheries Society, Manila, Philippines.

22. Tanasomwang V and L Ruangpan 1995. Bacterial flora of larvae of the black tiger shrimp, Penaeus monodon. In: Diseases in Asian Aquaculture II. (Shariff M, JR Arthur and RP Subasinghe Eds.), pp. 151-162. Fish Health Section, Asian Fisheries Society, Manila, Philippines.

23. Public Health England 2015. UK Standards for Microbiology Investigations-Identification of Vibrio and Aeromonas species. ID 19, Issue 3, $30 \mathrm{pp}$. The standards unit, Microbiology Services, PHE.

24. Rao BM and PK Surendran 2013. Pathogenic Vibrios in Penaeus monodon shrimp hatcheries and aquaculture farms. Fishery Technol. 50(2): 161-167.

25. Felix S 2000. Occurrence of pathogenic bacteria in shrimp farming systems of Tamil Nadu. J. Aquacult. Trop. 15(4): 365-369.

26. Stoskopf MK 1993. Bacterial diseases of marine tropical fishes. In: Fish medicine. (Stoskopf MK eds), $1^{\text {st }}$ edn, pp. 635-639. WB Saunders, Philadelphia.

27. Jayasree L, P Janakiram and R Madhavi 2006. Characterization of Vibrio spp. associated with diseased shrimp from culture ponds of Andhra Pradesh (India). J. World Aquacult. Soc. 37(4): 523-532.

28. Shapiro RL, S Altekruse, S Hutwagner, R Bishop, R Hammond and S Wilson 1998. The role of Gulf Coast oysters harvested in warmer months in Vibrio vulnificus infections in the United States, 1988-1996. J. Infect. Dis. 178(3): 752-759.

29. Vaseeharan B and P Ramasamy 2003. Abundance of potentially pathogenic microorganisms in Penaeus monodon larvae rearing systems in India. Microbiol. Res. 158(4): 299-308. 